\title{
PERANCANGAN DAN SIMULASI TURBIN PELTON DAYA OUTPUT GENERATOR 20.000 WATT
}

\author{
Ardy Hafid Ahrori \\ Fakultas Teknik, Program Studi Teknik Mesin \\ Universitas Muria Kudus \\ Email: ardyahrori92@gmail.com \\ Masruki Kabib \\ Fakultas Teknik, Program Studi Teknik Mesin \\ Universitas Muria Kudus \\ Email: masruki.kabib@umk.ac.id \\ Rianto Wibowo \\ Fakultas Teknik, Program Studi Teknik Mesin \\ Universitas Muria Kudus \\ Email: rianto.wibowo@umk.ac.id
}

\begin{abstract}
ABSTRAK
Air merupakan sumber daya alam sebagai pembangkit listrik merupakan alternatif untuk menggantikan kebutuhan akan bahan bakar minyak. Turbin bisa dibedakan dari daya yang dikeluarkan, pada turbin mikrohidro berjenis pelton, daya yang dikeluarkan sebesar 5 - $100 \mathrm{KW}$. Tujuan dari peneltian ini adalah untuk merancang turbin pelton daya outoput generator sebesar 20.000 watt dengan head jatuh air 12 meter. Metode yang digunakan dalam perancangan ini adalah studi literatur, proses perancangan, dan simulasi. Hasil perancangan dan perhitungan komponenkomponen turbin didapatkan untuk debit air $0,265 \mathrm{~m}^{3} / \mathrm{s}$, jumlah sudu sebanyak 18 buah, tinggi sudu $59,64 \mathrm{~mm}$, tebal sudu 25,56, dimensi luar runner sebesar 363,38, diameter pipa $147 \mathrm{~mm}$, kecepatan pancar air adalah $14,88 \mathrm{~m} / \mathrm{s}$. Desain yang sudah didapatkan selanjutnya di masukkan kedalam software autodesk inventor CFD, dan hasil simulasi kecepatan pancar air menggunakan software autodesk inventor CFD didapat kecepatan maksimum terjadi pada detik 0,6 sebesar 12,96 m/s.
\end{abstract}

Kata kunci : Mikrohidro, Turbin Pelton, generator.

ABSTRACT

The water is a natural resource to power plant, it is an alternative to replace the need for fuel oil. Turbines can be distinguished from the power released. The Pelton type microhydro turbines, that the power released is from $5-100 \mathrm{KW}$. The objective of research is to design of 20,000 watts of pelton turbine power outoput with 12 meters of water fall head. The method of desain is the study of literature, the design process and simulation. Teh design result was calculation of turbine components, the water discharge is $0.265 \mathrm{m3} /$ $s$, the number of blades is 18 pieces, the blade height is $59.64 \mathrm{~mm}$, the blade thickness is 25.56, the outer dimensions of the runner are 363.38, the pipe diameter is $147 \mathrm{~mm}$, the absolute speed of the nozzle is 14.88 $\mathrm{m} / \mathrm{s}$. The design was simulation with the CFD Inventor Autodesk software and the results of the simulation of absolute nozzle speed using the CFD Inventory Autodesk software occur at 0.6 seconds maximum speed of $12.96 \mathrm{~m} / \mathrm{s}$.

Keywords : microhydro, peltone turbine, generator 


\section{PENDAHULUAN}

Energi potensial air sudah banyak dimanfaatkan masyarakat secara luas dan digunakan untuk pembangkit listrik. Potensi air sebagai energi terutama digunakan sebagai penyedia energi listrik tenaga air ataupun mikrohidro. Tenaga potensial yang terkandung dalam air adalah dari tinggi jatuh air atau akibat dari debit air yang mengalir dari sungai [1].

Turbin memiliki komponen-komponen utama yang harus tahan dari air dan korosi, tahan dari proses kerja turbin itu sendiri dalam menghasilkan tenaga listrik sesuai daya rencana output generator yang dikeluarkan. Guna memenuhi kebutuhan tersebut, maka dibuat desain turbin yang mendukung untuk keluaran daya rencana keluaran generator [2].

Prototype turbin pelton sebagai alternatif mikrohidro, setelah mengetahui diameter dari runner sebesar $37 \mathrm{~cm}$, dengan memvariasikan jumlah sudu 18, 20, dan 22, dan memvariasikan debit airnya mulai dari 30 1/m, 28 1/m, dan $261 / \mathrm{m}$. Setelah dilakukan beberapa kali analisa bahwa turbin pelton yang paling efisien adalah menggunakan sudu 20 buah dan debit air $301 / \mathrm{m} \mathrm{[3].}$

Analisa kapasitas aliran air terhadap daya turbin dengan perbedaan kapasitas aliran daya pada dimeter nosel $3 \mathrm{~mm}$ dengan kapasitas aliran $15 \mathrm{~L} / \mathrm{min}$ dapat diketahui bahwa nosel dengan bukaan katup $35^{0}$ debit aliran fluida yaitu sekitar $2,5 \times 10^{-4} \mathrm{~m}^{3} / \mathrm{s}$ dengan putaran yang dihasilkan $1321 \mathrm{rpm}$ dan daya turbin 1.293 watt, dan pada katub bukaan $35^{0}$ dengan debit air $2,2 \times 10^{-4} \mathrm{~m}^{3} / \mathrm{s}$ didapatkan putaran $1311 \mathrm{rpm}$ dan daya turbin 1.234 watt. Hal ini membuktikan semakin besar kapasitas aliran semakin besar daya yang dihasilkan turbin [4].

Hasil perancangan dan pengujian turbin pelton pada debit air konstan dengan level terjun air sedikit berubah disebabkan pengaruh pemasangan sudut sudu $60^{\circ}$ memiliki torsi yang paling besar dengan sudut sudu $40^{\circ}$ dan $50^{\circ}$. Penambahan sudut sudu menyebabkan kecepatan putar menurun diikuti dengan menurunnya torsi. Untuk meningkatkan kinerja turbin maka jatuh kecepatan putar berbeban sudu tidak lebih dari 50\%. Penurunan kecepatan putar turbin diakibatkan oleh pembebanan justru akan menurunnya torsi bukan malah sebaliknya [5].

Hasil penelitian dan perancangan untuk mengetahui potensi PLTMH dengan menggunakan software autodesk CFD, dengan menggunakan perangkat lunak fluen dapat diketahui kondisi operasi turbin dan fenomena termodinamikannya. Aliran air pada pipa turbin berdiameter 6 inc, dan diamter luar turbin $338 \mathrm{~mm}$ dengan kecepatan variasi aliran air $2 \mathrm{~m} / \mathrm{s}, 3 \mathrm{~m} / \mathrm{s}, 4 \mathrm{~m} / \mathrm{s}$ didapatkan dari hasil hasil simulasi dengan software autodesk CFD menunjukkan bahwa semakin besar kecepatan inlet, maka semakin besar pula momen yang dihasilkan oleh sudu turbin [6].

Simulasi pada fluida masuk menggunakan software inventor CFD mengenai sudu, menyebabkan sudu bergerak searah jarum jam, selanjutnya ada fluida bergerak disebalah kanan shaft yang menuju outlet tetapi sebelum keluar fluida mengenai sudu lagi, baru keluar lewat outlet. Tekanan maksimal terjadi pada bagian punggung sudu sebesar 4,54e + $04 \mathrm{~Pa}$ [7].

Penelitian ini bertujuan merancang komponen-komponen turbin pelton yang telah dilakukan perhitungan manual sebelumnya, guna mendapatkan daya output keluaran dari generator sebesar 20.000 watt dengan head jatuh air 12 meter [8].

Simulasi pada turbin ini dibutuhkan untuk memberikan kemudahan dan keleluasaan dalam melakukan percobaan penelitian, dalam penelitian ini simulasi dibutuhkan untuk mengetahui kecepatan air dari nosel untuk memutar runner menggunakan software CFD [9].

Perancangan turbin pelton ini dengan daya output generator dan head jatuh air 12 meter memiliki kelebihan dibanding turbin lain dari segi head efektif dan dari segi daya keluarannya [10].

\section{METODOLOGI PENELITIAN}

Proses perancangan dan simulasi turbin pelton daya output generator 20.000 watt dan head jatuh air 12 meter ini dilakukan dengan langkah - langkah sebagaimana di ditunjukkan pada gambar 1 dibawah ini. 


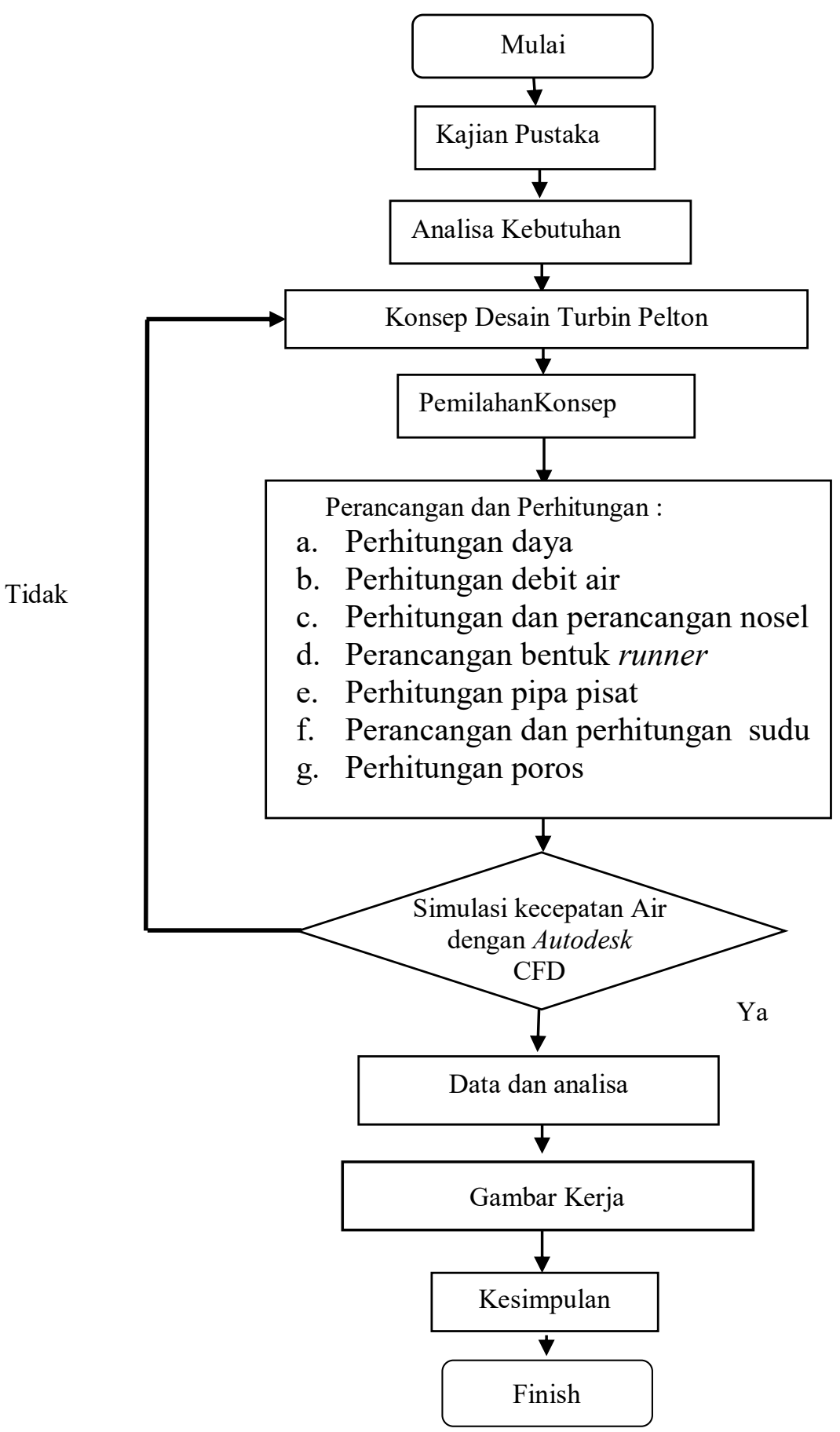

Gambar 1. Diagram alir perancangan

Tahap awal dilakukan kajian pustaka tentang teori dan penelitian sebelumnya, agar dapat membahas bagaimana cara melakukan perancangan turbin dari penelitian yang sudah dilakukan oleh orang lain sebelumnya. Analisa kebutuhan perancangan turbin pelton ini memiliki beberapa aspek diantaranya aspek teknik, aspek manufaktur, aspek perawatan, aspek lingkungan, dan aspek 
ekonomi. Proses ini diharapkan dapat tercapainya perancangan turbin pelton untuk meningkatkan efisiensi dan kinerjanya. Konsep desain perancangan turbin pelton ini basa dikatakan desain gambar yang akan mendasari penalaran, logika, serta pemikiran untuk bagaimana mendesain turbin beserta komponen-komponennya yang didasari dari perhitugan analitis. Pemilihan konsep turbin pelton ini sesuai dengan kebutuhan supaya mendapatkan hasil yang sesuai perencanaan. Proses perhitungan dan perancangan turbin pelton ini di mulai dari perhitungan daya, perhitungan debit air, perancangan dan perhitungan nosel, perancangan dimensi-dimensi runner, perancangan pipa pesat, perancangan dan perhitungan sudu, perhitungan poros dan setelah mendapatkankan hasil maka akan dilakukan proses simulasi dengan autodesk CFD guna mengetahui kecepatan pancar air yang dibutuhkan untuk memutar runner, data dan analisa hasil simulasi kecepatan air, dan setelahnya adalah gambar kerja turbin yang sudah dilakukan perhitungan dan perancangan sebelumnya.

\section{HASIL DAN PEMBAHASAN}

\subsection{Konsep Desain}

Konsep disini dimaksudkan desain yang akan mendasari logika, pemikiran, serta penalaran untuk bagaimana mendesain turbin pelton dengan perancangan dan perhitungan. Perancangan turbin yang dibuat ini diharapkan bisa mendapatkan rancangan yang sesuai dengan daya rencana yang dikeluarkan oleh generator sebesar 20.000 watt dengan head jatuh air 12 meter, konsep desain dapat dilihat pada gambar 2 dan 3 di bawah ini

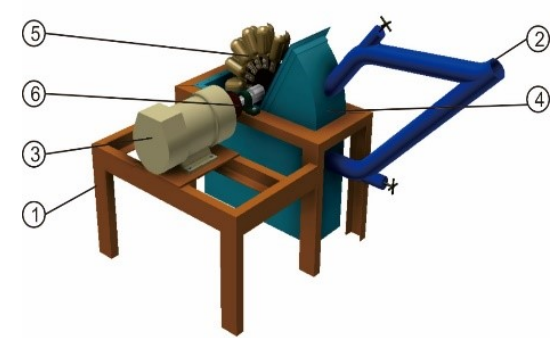

Gambar 2. Konsep 1

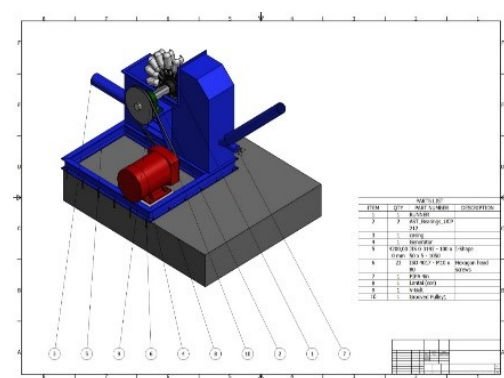

Gambar 3. Konsep 2

Konsep terpilih adalah konsep 2, turbin pelton dengan 1 nosel lebih cocok diaplikasikan di pedesaan dan perlu dilakukan proses simulasi untuk mengetahui kecepatan pancar air dari menggunakan software autodesk CFD. Konsep terpilih cenderung pada konsep kedua, turbin pelton dengan 1 nosel lebih cocok diaplikasikan di pedesaan dan perlu dilakukan proses simulasi untuk mengetahui kecepatan pancar air dengan menggunakan software autodesk CFD. Jumlah nosel pada desain 1 dan pada konsep 2 berjumlah 2 nosel yang kurang cocok dipakai di pedesaan karena membutuhkan debit air yang besar. Rangka pada desain pertama menggunakan jenis besi UNP 100 meter, sedangkan rangka pada konsep kedua menggunakan besi plat mild steel $10 \mathrm{~mm}$ IWF 100x500 yang cukup kokoh dalam pengaplikasiannya. Runner dengan bahan alumunium alloy (6061) yamg dari bahan tahan korosi. Pembuangan air konsep pertama terdapat di bawah rangka, sedangkan tempat pembuangan air dikonsep 2 menggunakan pipa tersendiri. Dudukan pada konsep kedua menggunakan besi IWF, sedangkan untuk bahan material pipa pesat menggunakan bahan iron.

\subsection{Penjelasan komponen - komponen turbin pelton}

Pipa pesat memliki fungsi untuk mengalirkan air dari head yang ditentukan ke nosel, selanjutnya nosel adalah bagian penting dari turbin yang berfungsi menmbakkan air ke sudu turbin, sudu turbin berbentuk mangkuk yang dipasang di sekeliling roda jalan atau runner dan generator berfungsi sebagai alat untuk merubah energi mekanik menjadi energi kinetik. 


\subsection{Perhitungan dan Perancangan}

Pada proses perencanaan perancangan turbin pelton, dibutuhkan perhitungan dan perancangan untuk mendapatkan desain yang sesui dengan rencana. Proses perhitungan dan perancangan turbin meliputi perhitungan daya, perhitungan debit air, perancangan nosel, perancangan runner, perancangan pipa pesat, dan perhitungan poros.

\subsection{Perhitungan Daya}

Perencanaan perhitungan daya bertujuan untuk menentukan seberapa besar daya turbin dan daya generator. Perhitungan daya turbin dapat mengunakan rumus persamaan 1 sebagai berikut[10] :

$$
P_{\text {Out }}=\frac{P_{\text {Generator }}}{\eta_{\text {Generator }}} \times 100 \%
$$

Perhitungan daya keluaran turbin $\left(P_{\text {out }}\right)$ didapat dari hasil bagi daya generator $\left(P_{\text {geneator }}\right)$ dibagi dengan efisiensi generator $\left(\eta_{\text {generator }}\right)$ dimana dalam spesifikasi generator terdapat nilai efisiensi sebesar 0,8 .

Perhitungan debit air dilakukan berdasarkan parameter sebagai berikut. Daya turbin 25000 watt head 12 meter dan grafitasi 9,81 dapat digitung dengan persamaan 2 [8] : $Q=\frac{P_{\text {in }}}{p \cdot g \cdot h}$

Debit air (Q) dapat dicari dengan perasaam rumus diatas dimana daya air ( $\left.P_{\text {in }}\right)$ di bagi dengan grafitasi bumi $(\mathrm{g}=9,81)$ dan head jatuh air $(\mathrm{h})=12$ meter.

\subsection{Perhitungan nosel}

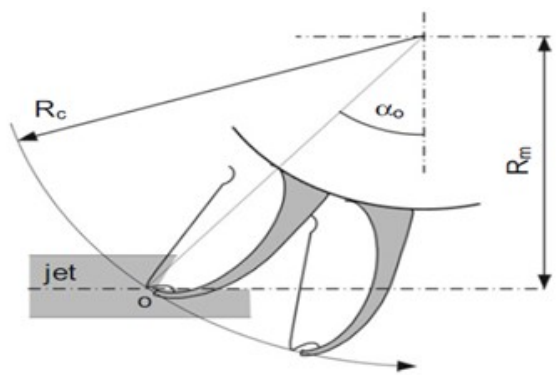

Gambar 4. Perbedaan kecepatan tangensial dan kecepatan pancar air

Pada gambar 4 menunjukkan perbedaan kecepatan tangensial dan kecepatan pancar air. Nosel merupakan bagian dari turbin pelton yang berfungsi sebagai pemancar air untuk menembakkan air ke arah sudu turbin. Kecepatan pancar air $\left(\mathrm{C}_{1}\right)$ dari nosel didapat dengan rumus persamaan 3 [3]:

$C_{1}=K_{C} \cdot \sqrt{2 \cdot g \cdot h}$

Nosel memiliki nilai koefisien tersendiri sebesar $(0,96-0,98)$ dengan grafitasi bumi (g) 9,81 dan head jatuh air (h) 12 meter.

Untuk kecepatan tangensial nosel bisa dicaari dengan rumus persamaan 4 [7]:

$u=\frac{C_{1}}{2}$

Kecepatan tangensial (u) bisa di cari dengan persamaan rumus diatas, hasil bagi kecepatan pancar air $\left(\mathrm{C}_{1}\right)$ di bagi 2 , untuk memperoleh nilai $(\mathrm{u})$. 


\subsection{Perancangan runner}

Perhitungan sudu turbin yang berbentuk mangkuk yang dipasang di sekeliling roda jalan (runner) dapat diketahui dengan rumus persamaan 5 [8] :

$$
D=\frac{60 \times u \times i}{\pi \times n_{\text {generator }}}
$$

Perhitungan runner dapat dihitung dimensi- dimensinya dari lebar sudu (b) dengan megkalikan diameter dalam nosel $(\mathrm{d}) \times 28,4$ kelonggran cetakan $(\mathrm{k})=0,1 \times \mathrm{D}$ (diamter luar runner) dan tebal sudu $(\mathrm{t})=0,9 \times \mathrm{d}($ dimater dalam nosel). Setelah melakukan perhitungan dideapatkan desain pada gambar 5(dimensi runner) dan gambar 6 (bemtuk sudu).

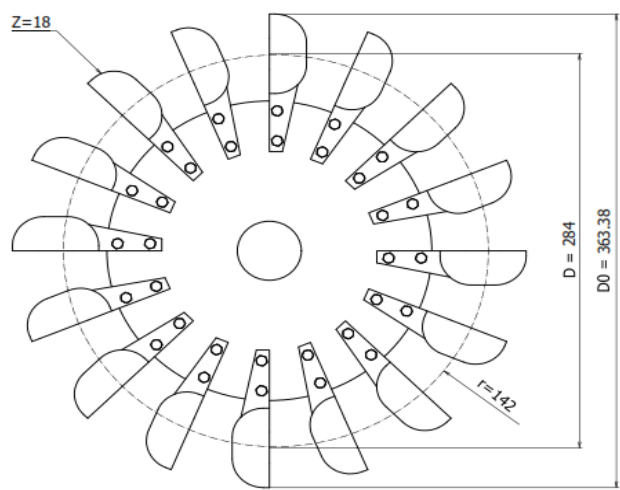

Gambar 5. Dimensi- dimensi runner
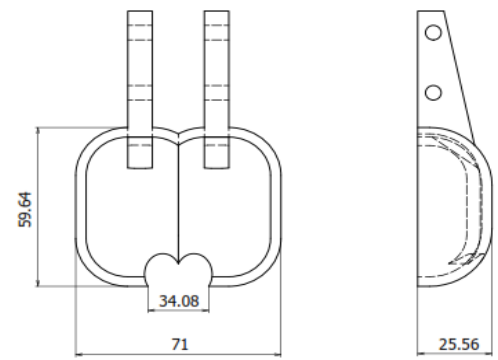

Setelah melakukan perhitungan dan perancangan dari dimensi - dimensi runner, maka diperoleh desain runner turbin seperti pada gambar 5 gambar runner dan gambar 6 , bentuk mangkuk dari desain turbin pelton.

\subsection{Perhitungan pipa pesat}

Perhitungan pipa pesat didapat dari debit air $(\mathrm{m} / \mathrm{s})$ dibagi kecepatan pancar air didapat dengan rumus $6[8]$ :

$A=\frac{Q}{C_{1}}$

Luas penampang (A) pada pipa di dapatkan dari hasil bagi debit air (Q) dengan kecepatan pancar $\operatorname{air}\left(\mathrm{C}_{1}\right)$

Diameter pipa pesat dapat dihitung dengan rumus persamaan 7 [8] :

$d_{\text {pipa }}=\sqrt{\frac{4 \cdot A}{\pi}}$

Pipa pesat dalam perancangan turbin pelton ini memiliki dimater sendiri untuk mencari diamter pipa $\left(d_{\text {pipa }}\right)$ pesat dapat dihitung dengan persamaan diatas dimana nilai luas penampang pipa (A) di bagi dengan nilai $\pi=3,14$. Hasil perhitungan komponen-komponen turbin pelton ditunjukkan pada tabel 1 . 
Tabel 1. Hasil perhitungan komponen-komponen turbin pelton

\begin{tabular}{cc}
\hline Perhitungan & Hasil \\
\hline Daya keluaran turbin & $25.000 \mathrm{watt}$ \\
Debit air & $0,265 \mathrm{~m} / \mathrm{s}$ \\
Keceptan pancar air & $14,88 \mathrm{~m} / \mathrm{s}$ \\
Kecepatan tangensial & $7,44 \mathrm{~m} / \mathrm{s}$ \\
Dimeter luar runner & $284 \mathrm{~mm}$ \\
Dimeter nosel & $28,4 \mathrm{~mm}$ \\
Lebar mangkuk & $71 \mathrm{~mm}$ \\
Jumlah mangkuk & $18 \mathrm{buah}$ \\
Tebal mangkuk & $25,56 \mathrm{~mm}$ \\
Luas penampang & $0,017 \mathrm{~m}^{2}$ \\
\hline
\end{tabular}

\subsection{Simulai kecepatan air dengan software autodesk CFD}

Proses pemodelan geometri turbin pelton menggunakan perangkat lunak Autodesk Inventor 2015 yang kemudian akan dianalisa dengan software Autodesk CFD. Pada tahap pemodelan dari awal hingga selesai menghasilkan gambar 7 yang nanti desain tersebut yang akan di lakukan proses simulasi.

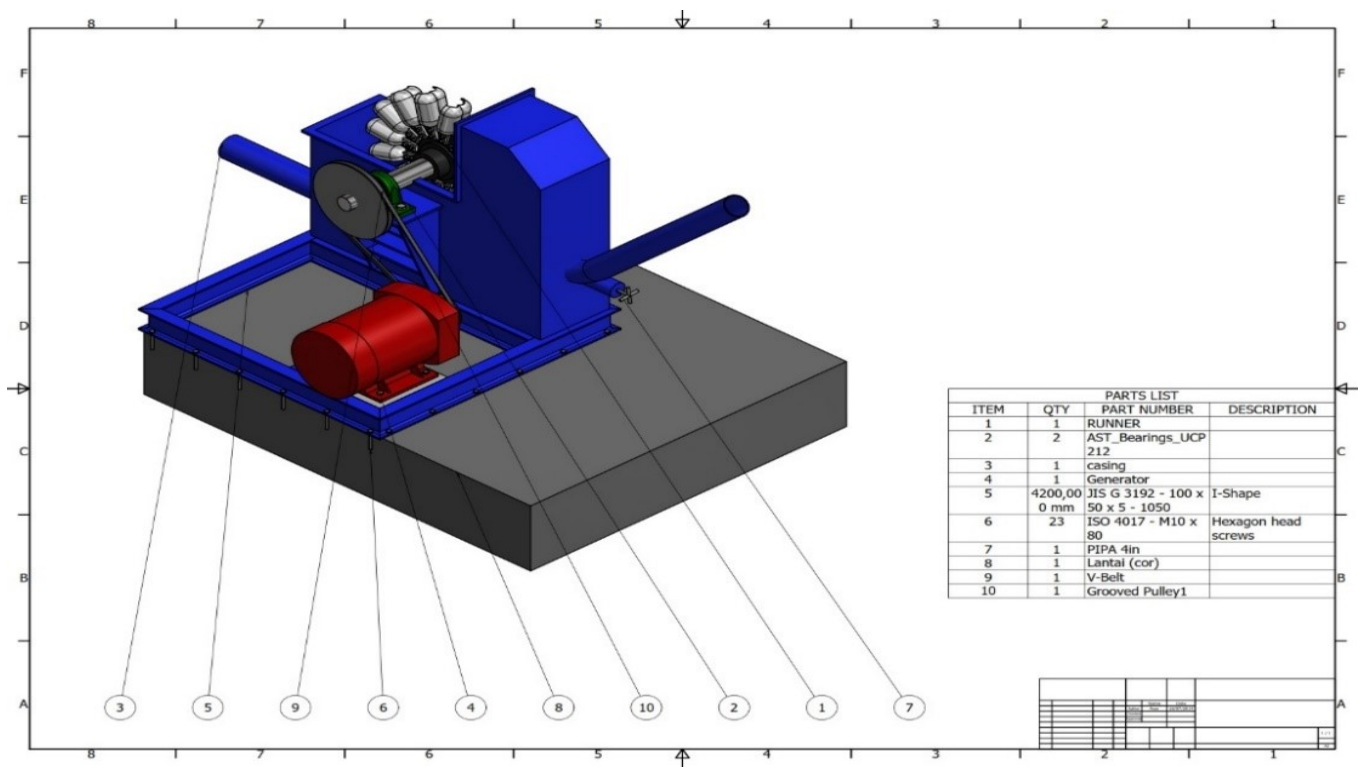

Gambar 7. Desain terpilih

\subsection{Hasil simulasi kecepatan air pada ujung nosel}

Desain turbin kemudian di masukkan kedalam software CFD, dengan memasukkan parameter yaitu debit air yang sudah di hitung manual sebelumnya sebesar $0,265 \mathrm{~m}^{3} / \mathrm{s}$ dan desain runner yang sudah di dabat untuk simulasi kecepatan pancar air diujung nosel dari software autodesk CFD mendapatkan hasil seperti pada tabel 2. 
Tabel 2 Kecepatan air diujung nosel

\begin{tabular}{ccc}
\hline No & Iterations $(\mathbf{s})$ & $\begin{array}{c}\text { Velocity Magnitude } \\
(\mathbf{m m} / \mathbf{s})\end{array}$ \\
\hline 1 & 0.1 & 9031.67 \\
\hline 2 & 0,2 & 10226.5 \\
\hline 3 & 0,3 & 12855.1 \\
\hline 4 & 0,4 & 11758.4 \\
\hline 5 & 0,5 & 11928.6 \\
\hline 6 & 0,6 & 3788.61 \\
\hline 7 & 0,667883 & 10471,9 \\
\hline
\end{tabular}

Pada detik ke 0.3 kecepatan air diujung nosel sebesar $12855.1 \mathrm{~mm} / \mathrm{s}$ dan menunjukkan hasil yang mendekati perhitungan manual. Simulasi kecepatan pancar air dalam bentuk grafik seperti pada gambar 8 .

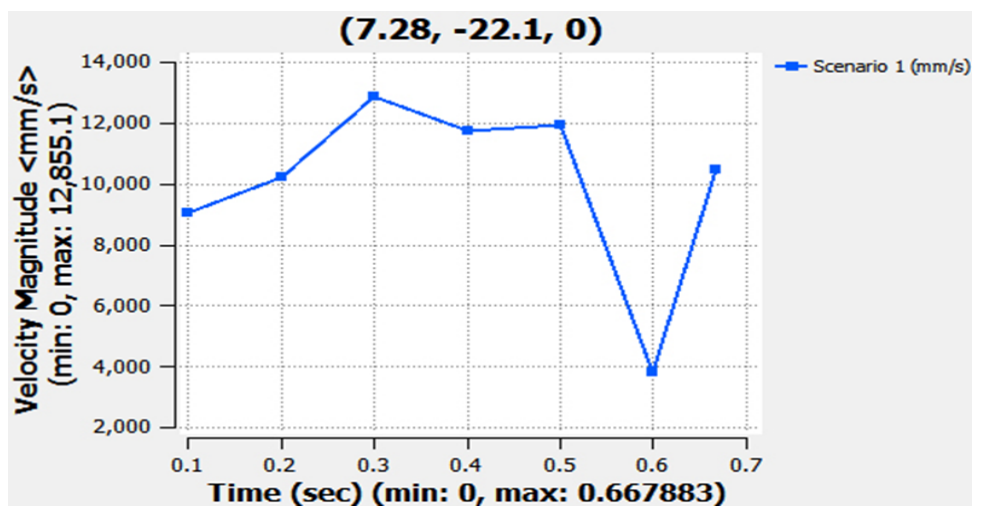

Gambar 8. Simulasi kecepatan pancar air dalam bentuk grafik

Dari hasil simulasi kecepatan air pada area nosel ditunjukkan pada gambar 8 didapatkan pada waktu 0.1 detik kecepatan air sebesar $9031.67 \mathrm{~mm} / \mathrm{s}$, pada waktu 0.2 detik kecepatan air sebesar $10226.5 \mathrm{~mm} / \mathrm{s}$, pada waktu 0.3 detik kecepatan air sebesar $12855,1 \mathrm{~mm} / \mathrm{s}$, pada waktu 0,4 detik kecepatan air sebesar 1198,6 mm/s, pada waktu 0.5 kecepatan air sebesar 1198,6 mm/s, pada waktu 0.6 detik kecepatan air sebesar 37888,61 mm/s. Pada waktu 0.667883 kecepatan air sebesar 10471,9 $\mathrm{mm} / \mathrm{s}$.

Hasil simulasi dengan autodesk CFD perbandingan waktu dan kecepatan air di area mangkuk seperti pada tabel 3 .

Tabel 3 Kecepatan air di area mangkuk

\begin{tabular}{ccc}
\hline No & Iterations $(\mathbf{s})$ & Velocity $(\mathbf{m m} / \mathbf{s})$ \\
\hline 1 & 0.1 & 2266.94 \\
\hline 2 & 0,2 & 4393.12 \\
\hline 3 & 0,3 & 6696.43 \\
\hline 4 & 0,4 & 10344.2 \\
\hline 5 & 0,5 & 12555.6 \\
\hline 6 & 0,6 & 12969.9 \\
\hline 7 & 0,667883 & 11184.6 \\
\hline
\end{tabular}


Pada detik ke 0.6 kecepatan pancar air maksimum sebesar 12969,9 mm/s. Hasil simulasi dalam bentuk grafik ditunjukkan pada gambar 9 .

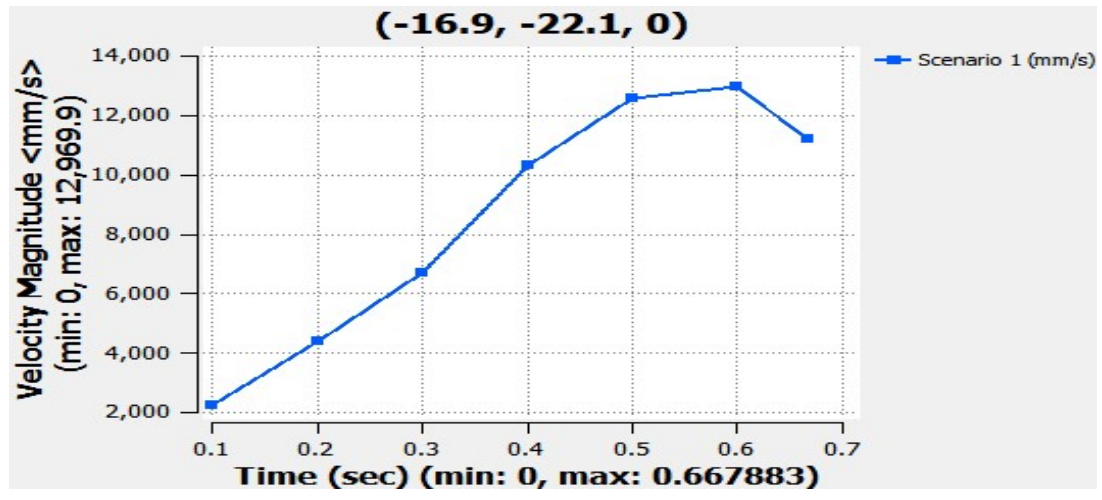

Gambar 9. Kecepatan pancar air dalam bentuk grafik

Kecepatan air pada area mangkuk ditunjukan gambar 9, pada waktu 0.1 detik kecepatan air sebesar $2266.94 \mathrm{~mm} / \mathrm{s}$, pada 0.2 detik kecepatan air sebesar $4393,12 \mathrm{~mm} / \mathrm{s}$, pada waktu 0.3 kecepatan air sebesar $6696.43 \mathrm{~mm} / \mathrm{s}$, pada waktu 0.4 kecepatan air sebesar $10344.2 \mathrm{~mm} / \mathrm{s}$. pada waktu 0.5 kecepatan air sebesar $12555.6 \mathrm{~mm} / \mathrm{s}$, pada waktu 0.6 kecepatan air sebesar $12969.2 \mathrm{~mm} / \mathrm{s}$, pada waktu 0.667883 kecepatan air sebesar $11184.6 \mathrm{~mm} / \mathrm{s}$.

Hasil dari perhitungan kecepatan pancar air $\left(\mathrm{C}_{1}\right)$ adalah $14,88 \mathrm{~m} / \mathrm{s}$. Sedangkan dari hasil simulasi kecepatan pancar air maksimal menggunakan software CFD, didapatkan kecepatan air sebesar $12969.9 \mathrm{~mm} / \mathrm{s}$ atau $12,96 \mathrm{~m} / \mathrm{s}$.

\section{KESIMPULAN}

Hasil perancangan turbin pelton daya output generator 20.000 watt dengan head jatuh air 12 meter dapat di simpulkan telah didesain turbin pelton untuk daya keluaran generator sebesar 20.000 watt dengan head jatuh air 12 meter. Dari perhitungan komponen- komponen turbin pelton didapatkan runner dengan diameter luar $363,38 \mathrm{~mm}$, lebar mangkuk $59,65 \mathrm{~mm}$, lebar bukaan mangkuk 38,04 mm, tinggi mangkuk 59,65 mm dengan debit air sebesar 0,265 m³ dengan luas penampang pipa sebesar $0,017 \mathrm{~m}^{2}$, sudut elevasi dari pipa pesat adalah $26,56^{0}$, Pada proses simulasi kecepatan pancar air di area mangkuk dengan menggunakan sofware autodesk $C F D$, kecepatan maksimum terjadi pada detik 0.6 yaitu sebesar $12,96 \mathrm{~m} / \mathrm{s}$. Dan pada hitung analitis $\left(\mathrm{C}_{1}\right)$ dari kecepatan pancar air nosel didapatkan $14,88 \mathrm{~m} / \mathrm{s}$.

\section{DAFTAR PUSTAKA}

[1] Bono, Indiarto. 2008. "Karakterisasi Daya Turbin Pelton Microhydro Dengan Variasi Bentuk Sudu”. Seminar Nasional Aplikasi Sains dan Teknologi, IST AKPRIND Yogyakarta

[2] Ceri Stuwerd Poea. 2012. "Perancangan Turbin Air Micrhidro Jenis Pelton Untuk Pembangkit Listrik Didesa kali Dengan Head 12 meter"Jurnal Online Poros Teknik Mesin, UNSRAT, Vol.1 No.1 2012.

[3] Gatot Suwonto. 2011 "Karakterisasi Daya Turbin Pelton Sudu Silinder Dengan Diameter Nosel".Seminar Nasional Sains dan Teknologi, Vol. 1, No. 1, UNWAHAS.

[4] Lal Jagdish. (1975). Hydrolic Machine, Published by Metropolitan Book Co.Pvt Ltd.

[5] Alfri Novaris, Budi, S Kurnia. 2010. "Modifikasi Pembangkit Listrik Tenaga Air Dengan Menggunakan Turbin Pelton". Tugas Akhir, Teknik Mesin UNDIP.

[6] Anjar Susatyo. 2003. "Perancangan Turbin Pelton", Puslit Tenaga Listrik dan Mekatronik, Pusat Penelitian Informatika - LIPI 
[7] Edy Suryono dan Aeb Nusantara,"Simulasi Turbin Crosflow Dengan Jumlah Sudu 18 Sebagai Pembangkit Listrik Picohydro," Simetris J. Tek. Mesin, Elektro Dan Ilmu Komput., Vol. 8, No. 2, November, 2017.

[8] Pamungkas Irwan. 2011. "Rancang Bangun Turbin Pelton Sistem Pembangkit Microhydro Dengan Variasi Bentuk Sudu”, Jurusan Teknik Mesin, Politeknik Negeri Semarang. 